\title{
REDISCOVERY OF SALVIA FREYNIANA BORNM. (LAMIACEAE), A CRITICALLY ENDANGERED SPECIES IN TURKEY
}

\author{
Safi Bagherpour, Ferhat Celep ", Musa Doğan and Ahmet Kahraman
}

Middle East Technical University, Department of Biological Sciences, 06530, Ankara-Turkey

Key words: Salvia freyniana Bornm., Lamiaceae, Endangered, Rediscovery, Turkey

\begin{abstract}
In 1890, Salvia freyniana Bornm., an endemic species of Turkey, was first collected and described by J.F. Bornmueller in 1892. While revising the genus occurring in Turkey based on specimens collected from Yenipazar, south of Yozgat (Turkey in 1892), it was discovered once again in 2006. The diagnostic morphological characters of this rare endemic species are discussed. Details of fruiting material and pollen micromorphology are given for the first time. Moreover, an emended and expanded description, distribution, phenology and ecology of this species are also provided along with its conservation status.
\end{abstract}

The genus Salvia L. (Lamiaceae: tribe Mentheae) represents a cosmopolitan assemblage of nearly 1000 species displaying a remarkable diversity in growth forms, secondary compounds, floral morphology and pollination biology (Walker et al. 2004). Salvia species are used in traditional medicines all around the world, possessing antibacterial, antioxidative, antidiabetic and antitumor properties (Ulubelen 2003).

The first revision of Salvia in Turkey was made by Hedge (1982), who recognized 86 species, one hybrid and one doubtful species. Since 2005, as a part of a revisional study of Salvia in Turkey, the authors have carried out extensive field studies and collected a large number of specimens. The studies have revealed two new species and two new records (Celep et al. 2009).

The objectives of this paper are to document the rediscovery of populations of $S$. freyniana, to provide its expanded morphological descriptions, distributions and habitats, to report the vegetation type and to accurately assess its conservation status. Pollen micromorphology and nutlet properties of the plant are also given.

During one of these field trips conducted in Yenipazar, South of Yozgat, an unusual population of Salvia was encountered. The specimens were cross-checked with the keys provided by Hedge (1982). The specimens were also compared with the herbarium specimens kept in ANK, AEF, B, BM, E, G, GAZI, H, HUB, ISTE, ISTF, K and KNYA herbaria. Finally, the specimens are identified as Salvia freyniana. Field and herbaria surveys have indicated that the species has not been collected since 1890 .

Pollen slides for morphological examination by light microscopy were prepared according to Wodehouse (1935). SEM images were used to describe surface texture of the pollens. The descriptive terminology of Faegri and Iverson (1975) was followed.

Salvia freyniana Bornmueller J.F. Plantae novae Orientalis. in Öst. Bot. Zeitschr. 42: 338-349, (1892).

(Fig. 1a-c)

Perennial suffruticose herb with a woody rootstock. Stems many, ascending to erect, 15-35 $\mathrm{cm}$ long, unbranched (rarely branched), greyish-green, dense eglandular antrorsely pilosepubescent with some villous hairs, similar with glandular capitate hairs above. Leaves pinnatisect with 1-2 pairs of lateral segments, terminal segments linear-oblong, 1.5-5.0 x 0.3-1.0 cm, greyishgreen, densely eglandular-pubesent to pilose with sessile glands, margins entire to crenulate towards apex, petiole $0.4-2.5 \mathrm{~cm}$ long, slightly widened at base, dense introrsely pubescent to

*Corresponding author. E-mail: fcelep@metu.edu.tr, ferhat_celep@hotmail.com 
pilose with long hair. Inflorescence racemose, clearly exceeding leaves with 3-6 verticillasters, each verticillasters with 2-8 flowered, distant. Bracts ovate to lanceolate, more or less white eglandular hairs, 4-10 x 2-5 mm. Bracteoles present. Pedicel 2-5 mm long. Calyx campanulate, 7$11 \mathrm{~mm}$ in fruits, with eglandular and glandular hairs. Corolla lilac-blue with white center, 10-18 $\mathrm{mm}$ long, tubes 6-13 $\mathrm{mm}$ long straight, annulate, upper lip straight. Stamens 2, anther two lobed, upper theca 1.9-2.7 mm long, the lower theca 1.0-1.3 mm long, filaments 2.7-3.2 $\mathrm{mm}$ long. Style glabrous, 16-20 mm long, exerted from corolla lips and stigma bifurcate.
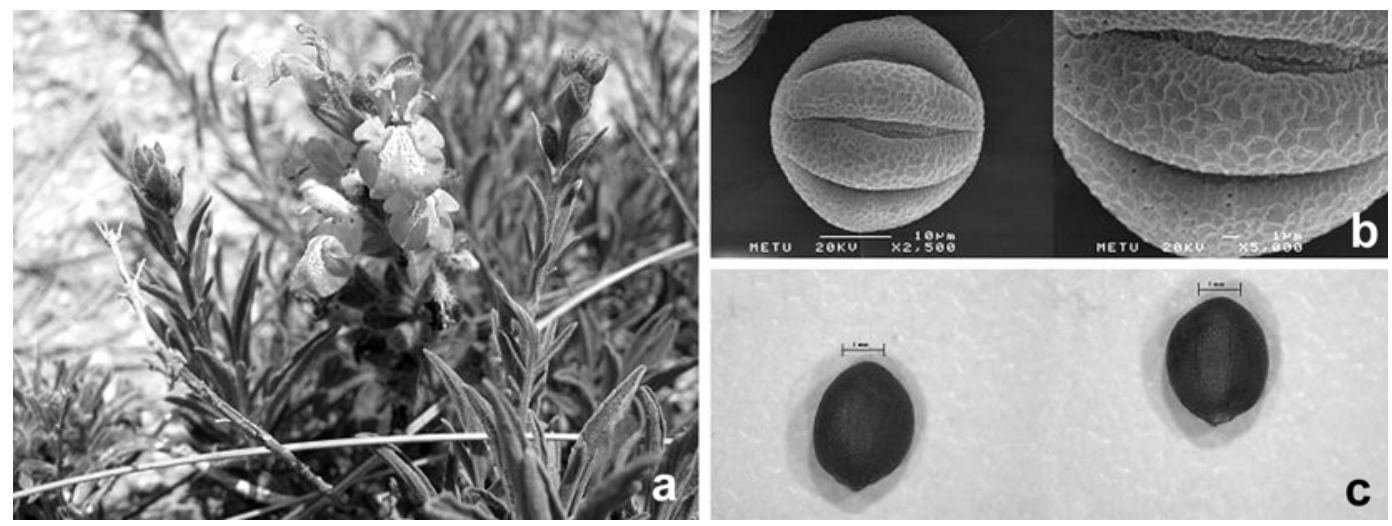

Fig. 1a-c Salvia freyniana. a. General appearence of the plant in its new locality. b. SEM micrographs of the pollen. c. Mature nutlets.

Typus: [Turkey B5 Yozgat] inter Caesaream (Kayseri) et Yosgad (inter pagos Köprüköi et Keller), 900-1000 m, 23 vi 1890, Bornmüeller 1730 (iso. BM!, G, K!, LD, W, Z).

New Locality: B5 Yozgat: South of Yozgat, Yozgat to Boğazlıyan, near Yenipazar, Kaşkışla village, hill side, around graveyard, 1100-1200 m, 4 vi 2006, A. Kahraman and S. Bagherpour 277.

Phenology: Flowering occurs in May to June and fruiting from June to July.

Distribution and recommended IUCN threatened category: Salvia freyniana, previously known only from the type locality, was discovered at another location near Yenipazar in Yozgat province.

Based on our data, its current conservation status has been re-evaluated. For the first time, it was assessed as Data Deficiency (DD) in Turkish Red Data Book (Ekim et al. 2000). According to the recent field survey conducted by the research team, the species is distributed in less than $5 \mathrm{~km}^{2}$ (criterion B2) and the mature plant number is less than 500 (criterion C). Therefore, it has been placed in Critically Endangered (CR) category (IUCN 2001).

Habitat and Ecology: Salvia freyniana grows on sandy soil. Its altitudinal range varies between 900 and $1200 \mathrm{~m}$. However, most populations are located at altitudes between 1000 and $1100 \mathrm{~m}$. Other species growing in the area are species of Astragalus, Bromus, Hordeum, Centaurea, Marrubium and some other herbaceous plants.

Scanning Electron Microscopy and pollen micromorphology: The pollen of Salvia freyniana is isopolar and oblate-spheroidal to prolate-spheroidal with $P=39.28 \pm 4.18 \mu \mathrm{m}$ and $E=38.54 \pm$ $1.5 \mu \mathrm{m}$ and $\mathrm{P} / \mathrm{E}=1.01$. The aperture is hexazonacolpate and the colpi are long, i.e. $C=33.45 \pm$ $5.58 \mu \mathrm{m}$. The exine is $1.52 \pm 0.4 \mu \mathrm{m}$ thick and the intine is $1.17 \pm 0.2 \mu \mathrm{m}$. Wall ornamentation is reticulate (Fig. 1b). 
Seed Morphology: Mature nutlets of S. freyniana were collected for the first time. They are rounded, trigonious and suboblate, dark brown, $3.15-4.0 \times 2.5-3.0 \mathrm{~mm}$, surface slightly tuberculate (Fig. 1c).

Salvia freyniana was collected in 1890 and described in 1892 by J.F. Bornmueller. However, since then it has not been collected from its unclear type locality. In Bornmueller's 1892 protologue, flower colour and seed characteristics were not properly described, probably due to lack of proper materials.

Thorough study of morphological characteristics of Salvia freyniana revealed some additional information to those data reported in Flora of Turkey (Hedge 1982). Characteristics of the leaf, the calyx, the corolla and the indumentum are determined to be more variable than the earlier account. In addition, Salvia freyniana is closely related to Salvia wiedemannii Boiss. However, there are morphological and geographical differences between these species. Salvia freyniana differs from Salvia wiedemannii on its clearly herbaceous habit, larger serrulate leaflet and campanulate calyx. Moreover, the species is distributed only in eastern parts of central Anatolia, at an altitude of 1000-1200 m. On the otherhand, Salvia wiedemannii is restricted to western parts of central Anatolia at an altitude of 500-1400 m.

\section{Acknowledgements}

Authors thank the curators of ANK, AEF, GAZI, HUB, ISTE, ISTF, E, K, BM, G and W herbaria for allowing to study their Salvia collections, and the Scientific and Technical Research Council of Turkey (TUBITAK-TBAG-104 T 450) for their financial assistance.

\section{References}

Celep F., M. Dogan and A. Duran. 2009. A new record for the Flora of Turkey: Salvia viscosa Jacq. (Labiatae). Turk. J. Bot. 33: 57-60.

Ekim T., M. Koyuncu, M. Vural, H. Duman, Z. Aytaç and N. Adıgüzel. 2000. Türkiye Bitkileri Kırmızı Kitabı (Red Data Book of Turkish Plants). Türkiye Tabiatını Koruma Derneği ve Van 100. Yıl Üniv. Yayınları, Ankara.

Faegri K. and J. Iversen. 1975. Textbook of pollen analysis. Hafner Pres, New York.

Hedge I.C. 1982. Salvia L. In: Flora of Turkey and the East Aegean Islands, Davis, P.H. (Ed.), Vol. 7: 400461. Edinburgh Univ. Press, Edinburgh.

IUCN. 2001. IUCN Red List Categories: Version 3.1. pp. 1-23. Prepared by the IUCN Species Survival Commission. IUCN, Gland and Cambridge.

Ulubelen A. 2003. Cardioactive and antibacterial terpenoids from some Salvia species. Phytochem. 64: 395-399.

Walker J.B., K.J. Sytsma, J. Treutlein and M. Wink. 2004. Salvia (Lamiaceae) is not monophyletic: Imlications for the systematics, radiation and ecological specializations of Salvia and Tribe Mentheae. Amer. J. Bot. 91(7): 1115-1125.

Wodehouse R.P. 1935. Pollen grains. McGraw-Hill, New York. 574 pp. 